\title{
REVIEW DIALOGUE
}

\section{Rodrigo's Third Chronicle: Care, Competition, and the Redemptive Tragedy of Race}

Two Nations: Black and White, Separate, Hostile, Unequal. By Andrew Hacker. $\dagger$ New York: Charles Scribner's Sons, 1992. Pp. xiii, 257. \$24.95 cloth.

\section{Reviewed by Richard Delgado $\ddagger$}

\section{INTRODUCTION: RODRIGO ACCOUNTS FOR HIS RECENT ACTIVITIES}

"Rodrigo, I was just thinking about you." This was not the usual hyperbole busy professors use to flatter their favorite students. Since returning froin iny talk at the Economics-of-Race conference, I had been meaning to call Rodrigo to thank him for helping me prepare for it. ${ }^{1}$ "How has the term been treating you?"

"Not bad. How was your conference?"

"Good. They're thinking of making a book out of the proceedings. If so, I'll get a chapter out of it. My talk went over well, thanks in part to our conversation."

$\dagger$ Professor of Political Science, Queens College, City University of New York.

$\ddagger$ Charles Inglis Thomson Professor of Law, University of Colorado. J.D. 1974, Boalt Hall School of Law, University of California, Berkeley.

1. See Richard Delgado, Rodrigo's Second Chronicle: The Politics and Economics of Race, 91 Mich. L. Rev. (forthcoming May 1993) [hereinafter Delgado, Second Chronicle]. In Second Chronicle, Rodrigo and I discuss recent conservative writing on the American race problen, including Richard A. Epstein, Forbidden Grounds: The CASE Against Employment DisCRIMINATION LAWs (1992). Our discussion by chance took place shortly before I spoke at a conference on the economics and politics of race and was quite helpful to me in getting niy thoughts in order. See also Richard Delgado, Rodrigo's Chronicle, 101 YALE L.J. 1357, 1357-59 (1992) [hereinafter Delgado, Chronicle], introducing Rodrigo Crenshaw, a U.S.-born African-American who has been living and attending law school in Italy. Rodrigo is the half-brother of well-known American civil rights attorney and activist Geneva Crenshaw. See DERRICK BELL, AND WE ARE Not SAVED: THE Elusive QuesT FOR RACial JUSTICE (1987) [hereinafter BeLL, Not SAVEd] (introducing and detailing the adventures of Geneva Crenshaw); Derrick Bell, Foreword: The Civil Rights Chronicles, 99 HARv. L. REv. 4, 13-17 (1985). He noved to Italy when his father, a U.S. serviceman, was assigned to an Italian base. Rodrigo completed high school at the base school, then attended an Italian university and law school, graduating near the top of his class. Additional facts about Rodrigo are introduced at different points in this narrative. E.g., infra notes 2-6, 60, 109 and aecompanying text. 
"You give me too much credit," Rodrigo replied. "I was just a sounding board. But if you have a minute, I need your ear in connection with something I'm working on myself."

"Glad to oblige, though I hope you'll first tell me about your LL.M. program. I feel I had some role in getting you started. ${ }^{2}$ How are things uptown?" I asked, motioning him to have a seat on my office couch. "Like some coffee?"

"You know my weakness," Rodrigo rephed. "I've been staying up late with two seminar papers, including the one I need to talk to you about."

\section{I \\ IN WHICH RODRIGO EXPLAINS HOW HE WON A NATIONAL ESSAY COMPETITION, SOLVED THE RIDDLE OF THE AGES, YET GOT INTO Trouble With His Seminar Professor}

As I busied myself making a pot of espresso on my office coffeemaker, Rodrigo launched into his tale:

"Things are going fine. Your Socratic method takes a hittle getting used to. But I'm enjoying myself, except for something curious that happened in my Social Legislation seminar. It's taught by a famous professor, someone you probably know. We had to write papers, so I wrote on a problem that I'd been thinking about for a while-namely, how to reconcile socialism and capitalism."

"No small challenge, Rodrigo!" I rephied. I was struck by his audacity but, on second thought, was not really surprised. The brash, talented Rodrigo never had been one to shy away from difficult challenges. " "So, you addressed the riddle of the ages, one that has troubled some of the finest poitical minds of our times?"

2. In Delgado, Chronicle, supra note 1, at 1361-64, Rodrigo seeks me out in my office, introduces himself, and describes his plan to obtain an LL.M. degree at an American institution in preparation for a career as a law professor. We have a wide-ranging discussion about affirmative action, the U.S. racial scene, and world cultures, an area which Rodrigo studied in school and in which he is well versed. Id. at 1365-76. At the end of our talk, I agree to write letters of recommendation on his behalf to a number of American law schools. Id. at 1379.

3. E.g. id. at 1366-70, 1375 (Rodrigo and I discuss narrative theory and double consciousness, the decline of the West, and a new theoretical basis for affirmative action).

4. I thought of the many writers who had struggled to explain and understand "welfarc capitalisın," a systein based on free market principles but nevertheless containing safety nets for the unfortunate. E.g., 1 KENNETH BouLdING, ECONOMIC ANALYsis 627-49 (4th ed. 1966) (arguing that Pareto optimality within a society inust take account of certain ethical ideas of what a "better" society is); JoHN K. Galbraith, The AfFluent SocieTY 1-5 (3d ed. 1976) (arguing that public expenditures must mcrease concurrently with private production in order to redress social ills); John K. Galbraith, The New INDUSTRial State 1-10 (4th ed. 1985) (arguing that the unodem economy no longer conforms to the idcal of frce market capitalisin). Contra ADAM SMITH, THE WEALTH OF NATIONS ch. 8 (Everyınan's Library 1991) (1776) (expounding the traditional viewsocial welfare increases as a natural result of the increasing wealth of a society). 
"You know that I studied world cultures before returning here." Plus, there has always been great interest in socialism and Marxism among Italian intellectuals. Yet, all iny professors here in the U.S. seem deeply committed to frec market solutions for everything. It struck me as an area warranting examination. So I resolved to see what I could do."

"And that's what you wrote about for your course paper?"

"Yes, and I won a national essay coinpetition for student writing. The judges loved it. I even received a small cash award, which I gave to my sister to pay her back for soine of the moving-in expenses she helped me with."6

"Congratulations!" I rephed. "Your professor must have been proud." Gesturing toward the shelf, I said, "Cream and sugar?"

"Thanks," said Rodrigo, pouring and stirring with gusto. "As a matter of fact, that's what I'm here to see you about. Patience has never been my strong point, and when I learned of the essay coinpetition, I sent a draft even before showing it to my professor. The deadline was in early Noveinber, and I felt confident enough of my analysis that I sent it in."

"And then what happened?"

"I got a phone call announcing the award. But my professor, although happy that I won, wants me to rewrite the paper. He says it's not legal enough. Plus, to do real justice to the topic, he says it really ought to be a book. But since there's not tune for that, he wants me to scale it down. He suggested that my next draft focus on race-on the 'probleins of iny people,' as he put it."

"Fascinating," I rephed. "They are always coinplaining that we cluster together in cafeterias and so forth, and only want to teach and write about civil rights. Then, when we address something of broad social interest, they want to herd us back into our cubbyholes as quickly as possible. It happens often. ${ }^{7}$ You'd think there would be a cuinulative einbarrassment effect, but apparently not. But tell me what your paper is about-the one that won the prize, I inean."

"As I said, Professor, I set out to reconcile socialism and capitalisin, the two principal systems of economic organization in the world. They've long been thought to be in conflict. So I thought that trying

5. Rodrigo completed his degree "at a law school even older than [mine]," Delgado, Chronicle, supra note 1, at 1359-60, and before that studied comparative world cultures while on scholarship at the same nniversity.

6. Following our first meeting and after solving a difficult immigration law problem, Delgado, Second Chronicle, supra note 1, at 2 n.2, 6, Rodrigo moved into an apartment uptown near the school where he would pursue his LL.M. studies.

7. See Richard Delgado, Minority Law Professors' Lives: The Bell-Delgado Survey, 24 HARv. C.R.-C.L. L. REv. 349, 367-68 (1989) (detailing problems of expected ethric specialization and expertise). 
to reconcile them would be a good thing to do, especially for a Social Legislation paper."

"Some very good minds have addressed this very problem, Rodrigo," I rephed wryly. ${ }^{8}$ "If you've pulled it off, you'd be a candidate for the Nobel Prize im law, if there were such a thing, not just first place in a student competition. Tell me how your analysis goes. Later, we can talk about what your professor wants in the way of a redraft. Incidentally, you shouldn't feel offended that he wants you to submit two drafts. It's a very common requirement in American law school courses."

"I know. He explained that during the first meeting. I just didn't expect the revision would take the direction he suggested-although, as you know, I'in fascmated by problems of race."9 Rodrigo peered at the jacket of a book lying open on iny desk. "I'm reading the same one. It looks like it might be useful for my rewrite."10

8. See supra note 4.

9. See generally Delgado, Chronicle, supra note 1 (dealing with issues of cultural nationalism and a new approach to affirmative action); Delgado, Second Chronicle, supra note 1 (dealing with the economics and politics of race).

10. ANDREW Hacker, Two Nations: Black aNd White, SeParate, Hostile, UNequal (1992). Hacker, a professor of political science at Queens College in New York City, is the author of numerous articles about race or American culture in such journals as The New York Review of Books, Time, Newsweek, Harper's, and The New Republic, as well as a well-regarded book, The End of the American Era. In Two Nations, Hacker paints a bleak portrait of the racial predicament of the Umited States. Drawing his title from a quotation by Benjamin Disraeli, Hacker shows, through a dazzling array of figures and statistics, that America today has in effeet become a nation divided into two separate camps, White and Black, one wealthy, the other poor, both hostile to one another.

In an arresting anecdote early in the book, Hacker describes how he puts the following question to his classes: Suppose that a government official visits you, a White person, and informs you that a mistake has becn made. You were to have been born Black. To correct this error, it will be necessary for you to assume a Black appearance and physical body, but your thoughts, memories, and personality will otherwise be the same. The government is prepared to compensate you for this error; how much will you want in return for going through life as a Black? Hacker reports that over the years, the response has remained the same: $\$ 50$ million, or a million dollars for each year of life. Id. at 31-32.

Early chapters, on "Race and Racism" and "Being Black in America," explain why the price is so high. A Black skin means that cab drivers (even those who are Black) will not stop for you, out of fear that they will be asked to drive to a part of the city where they would rather not go. Id. at 20. It mcans having few, if any, White friends, and living in a predominantly Black neighborhood. Studies show that when Blacks coinprise eight percent of a neighborhood, most Whites move out. Id. at 36. It means being treated as though you might infect a neighborhood sinply because of your race. Id. at 38. It means that at a gathering or on a job, you are likely to be the only one of your race; every eye will be on you. Id. at 39. It means most of the images you see of persons like yourself in the press and TV are bad. Id. at 39-40. You are a candidate for police harassinent, AIDS, high blood pressure, and early death. Id. at 46, 49. If you travel, it means worrying about the reception at restaurants and motels. Id. at 48. At stores, the clerks keep a watchful eye on you and take an unusually long time verifying your credit card. Id.

Other chapters dcal with White responses, liberal and conservative, to Black needs, id. at 50.64, and the einployment and the earnings gap (how much is due to prejudice and discrimination?). Id. at 93-133. Other sections deal with Black children and the role of schools, id. at 134-78, Black fanilies, id. at 67-92, and Black crime, id. at 179-98. Among Hacker's findings are that additional education raises Blacks' incomes less than it does Whites', id. at 95-96; the Black family incomc has remained about the same from 1970 to 1990 while that of Whites has risen cight percent, id. at 94 
I refilled Rodrigo's cup and sat back expectantly. Rodrigo loved to talk about books and ideas. ${ }^{11}$ And I was especially curious to learn his thoughts about socialism and free market capitalism, smce I had just returned from a conference on a related subject. ${ }^{12}$

"How did you decide on your topic?" I asked.

"I was reading about nursing home scandals, imcluding a recent case in which an elderly patient died for lack of care. ${ }^{13}$ Another LL.M. student, a friend of mine from Ghana, is writing about the problem of regulating such homes, so the issue was on my mind. It occurred to me that we have no such problem in Italy, nor im any other Mediterranean country I know about. And the same seems to be true of Black and Chicano culture here. No matter how poor an elderly person, there is generally someone who will take care of them."14

"I've heard of exccptions," I interjected. "But as a generalization, you may be right. It is mainly our friends of the majority race who seem most concerned about being alone and uncared for in their old ages."

"And this got me to thinking, not so much about White versus nonWhite differences, but the problem of care generally. It struck me that the caregiving sector of a society should almost always be socialized, while the productive sector should be relegated to the free market econoiny."

"A nice, elegant solution," I rephed. "But of course the law-andeconomists will argue that everything should be governed by the market, ${ }^{15}$ including nursing homes. Where, and why, do you draw the line?"

"Let me explaim by means of the example I just mentioned," Rodrigo replied, finishing his coffee and looking up animatedly. "The

98; $44 \%$ of Black children live below the poverty line, id. at 99-100; and gains in the Black middle class have been accompanied by a growth in Black poverty, id. at 98 . Although Blacks account for about $12.5 \%$ of the population, id. at 15, there are only 254 Black optometrists, 89 theology professors, and almost no Black CEOs or owners of firms with more than a handful of employees, $i d$. at 107-11. Black undergraduates at the nation's White-dominated colleges and universities must survive a climate of ethnoviolence and slurs. Id. at 147-52.

Rodrigo and I later turn to a discussion of Hacker's book, including Hacker's more interpretive passages. See infra notes 22, 24-25, 70-71, 73-81, 83-92, 94-95, 101, 107, 116-19 and accompanying text.

11. His two previous chronicles feature discussions of Dinesh D'Souza's Illiberal Education and of Richard Epstein's Forbidden Grounds. DINEsh D'Souza, Illiberal Education: The Politics of RACE AND SEX on CAMPUS (1991); EPSTEIN, supra note 1.

12. In Delgado, Second Chronicle, supra note 1, Rodrigo and I discuss a number of conservative or libertarian books in the law-and-economics vein.

13. Unfortunately, reports of such events are legion. E.g., Michael Booth, Four Deaths Probed at Bethany Care Center, DENv. Post, July 28, 1992, at A1 (investigation into four patient deaths at a single nursing home).

14. See Delgado, Chronicle, supra note 1, at 1376, 1383 (referring to "the seemingly more successful approach that African and Latino societies have taken to family organization and the treatment of their own aged and destitute" and histing related sources).

15. E.g., EPSTEIN, supra note 1, at 15-27 (concluding that governmental coercion and interference should have little or no role in ordering the private marketplace). 
nursing hoine had hired the minimum number of einployees they could get away with under the law. And they were all high school graduates or less. When the elderly patient went into a semi-coma, they were too busy to notice, even though the other patients tried to call his predicament to their attention. Three days later, the family came to visit him and, noticing his condition, called an outside doctor. But it was too late. The grandfather died the next day."16

"And the inoral you draw from this is ... ?"

"Caregiving and the profit motive are incoinpatible. The teinptation is to cut corners, which is contrary to what's needed. With caregiving, the focus has to be on the individual, not on the profit line. If what you need to dispense is love, compassion, nurturance, then you need to socialize the caregiving enterprise. That way, we all bear the cost of it, and can, if we decide, hire high-quality caregivers." 17

I sat up with interest. "And since our society is getting older, ${ }^{18}$ and none of us knows if he or she will need a caretaker sometine in the 'future, people can perhaps be inade to go along." I am considerably older than Rodrigo and have given nore than passing thought to what will happen to ine when I enter old age.

"With the productive sector," Rodrigo continued, "it's fine to try to cut corners. A firm that succeeds in reducing the price of a good or service will drive its competitors out, which is good and to be expected. ${ }^{19}$ But people are not commodities, not cans of soup. So with child care, nursing care, primary education, programs for the inentally ill and other dependent populations, we should socialize every one. Some we already do. We should do the same with all the rest, even if it costs nore in the short run."

"So, the trick is to draw the right line between the productive sector, which should be governed by aggressive, dog-eat-dog capitalisin-the sort of thing our conservative friends love-and the caregiving sector, which should be socialized. Model-fitting, as they say."

"Right. And that's what my original paper was about. I even gave examples of industries and services that we currently socialize, like the Post Office, that it makes no sense to treat that way. They ought to be relegated to the private sector as soon as possible."

"You may not know this, Rodrigo, because you've been living in Italy. But we've actually been coming around to that view. Recently,

16. Telephone interview with Peter Lomhoff, attorney-at-law (July 16, 1992).

17. Cf. Richard Delgado, Zero-Based Racial Politics: An Evaluation of Thrce Best-Case Arguments on Behalf on the Nonwhite Underclass, 78 GEo. L.J. 1929, 1937-40 (1990) (discussing the "communitarian" approach to social welfare).

18. Nancy R. Gibbs, Grays on the Go, Time, Feb. 22, 1988, at 66, 70 (statistics show that an increasing percentage of Americans are over 65).

19. For an early, and still classic, statement of marketplace theory, see generally SMITH, supra note 4. 
we've allowed companies like U.P.S. and Federal Express to compete with the Post Office for the dehvery of mail and packages. They've become very popular because they're faster and don't charge any more."

"I know. A friend of mine got an express package in Dublin one day from some friends in America. It got there in only two days; the mail usually takes a week. And when you think of it, it makes sense. There is no reason at all to have the Post Office be a socialized bureaucracy, other than that your Constitution makes some vague reference to one. ${ }^{20}$ The clerks are bored and slow. The Post Office can't attract imtensely idealistic persons with nurturing skills, since there's hittle about a letter to love. Nor is there the zest and élan associated with competitive enterprise-trying to deliver a service or good cheaper and better than the next business. No wonder complaints about the service run rampant."21

"Let's say we do what you suggest, Rodrigo. We commit all tle caregiving activities-the ones we can't handle as individuals, at any rate- to the public sector, and socialize them. And we relegate the Post Office, manufacturing, and otlier productive activities to the competitive sector. Won't this just set up two nations within one, with the idealistic caregivers working at jobs everyone will regard as second class? We already have this to some extent. ${ }^{22}$ Won't your plan just exacerbate it?"

"No," Rodrigo replied quickly, "because we'll be free to pay tlie caregivers a living salary. As you mentioned, this shouldn't be hard to arrange, because with an aging society everyone fears that they might need to be taken care of some day. ${ }^{23}$ But there are additional arguments."

"I'd love to hear tliem."

"Well, first of all, everyone today is seeing first hand the economic and psychic consequences of lack of care"-Rodrigo gestured toward the book on my desk-"all tlie things Professor Hacker writes aboutimcreased crime, ${ }^{24}$ juvenile delinquency, ${ }^{25}$ school dropouts ${ }^{26}$-and more. The case for socializing caregiving today is plainer and more urgent than ever before. Personalized, loving attention to dependent imdividuals is today a cultural mandate-one that even makes economic sense."

20. U.S. CoNsT. art. I, § 8, cl. 7.

21. E.g., Zachary Margulis, Neither Snow, nor Rain, but Huge Buildings Will Stay a Courier, NewSDAY, July 5, 1992, at 2 (discussing inefficient mail delivery and overtime costs resulting from high tenant turnover in urban apartment complexes).

22. See HACKER, supra note 10, at 105-06, 110-11 (arguing that creation of semi-skilled jobs for Black inen implies racial predisposition to certain oceupations and using statistics to show that a two-class job system already exists and is divided along racial lines).

23. See Gibbs, supra note 18, at 70-71 (noting that aging population is likely to need caretaking services).

24. HACKER, supra note 10, at 179-98.

25. Id. at 46, 187, 218.

26. Id. at $166-67,177$. 
"Then why not leave it to the private sector?"

"Because by its very nature, it is needed by those who can least afford it. We must socialize caregiving if it is to be effective."

"You may have a point, Rodrigo, but I'm still worried about the problem of second-class citizenship. With caregiving a function of the socialized sector and production left to the private side, won't all the caregivers end up being minorities, just like in the bad old days?"27

"No, I don't think so," Rodrigo rephied. "Many White folks have idealistic impulses, too, and would gladly work taking care of children, the aged, or the disabled if those jobs paid a decent salary. Some of thein do now, even with what they get paid. And for the inany caregivers who now suffer deinoralization and 'burn-out,' the better pay and greater prestige that would go with socialization may be the tonic they need to stay with their stressful, demanding jobs longer."28

I was silent for a moment while Rodrigo poured himself a second cup of coffee. I marvelled at his youthful constitution. Two cups of coffee in the afternoon would have had me awake half the night. "You mentioned there were a number of arguments in favor of your plan. What are the others?"

"One is synergy-interactions between the two sectors. The productive sector would develop technology for high-quahty caregiving-for example, monitoring nachines, wheelchairs, imteractive learning devices for young schoolchildren. They could sell these to the caregiving sector, conipensating for the somewhat higher tax bill the productive sector would have to absorb. At the same time the caregivers, free to give firstrate attention to their charges, should be able to send many of them into the private sector equipped with skills, a high self-iniage, and good job prospects. Currently, half a generation of inner-city children grows up unemployed or undereinployed-if they don't turn into criminals or drug dealers. ${ }^{29}$ Concentrated caregiving fronı an early age will redeem niany of then, enable them to becoine Thonias Edisons, Colin Powells, or Jonas Salks. Our economy would flourish, instead of sinking to the point where it is now barely in the top five in the world. ${ }^{30}$ You recall our discussion before, Professor."

"I do. And your ideas have a certain idealistic appeal. Certainly we should try anything rather than succumb to the predicanient Andrew

27. See supra note 22 and accompanying text.

28. On the stresses (and satisfactions) of life as an inner-city schoolteacher, see JONATHAN Kozol, Death at AN EARLy AGe (1967).

29. For a sobering discussion of African-Americans in public schools and the criminal justice system, see HACKER, supra note 10, at 134-98.

30. U.S. Gets Less Competitive as Japan Stays on Top, Annual Survey Indicates, ATLANTA J. \& CoNST., June 22, 1992, at A10 (U.S. economy dropped to fifth most competitive, and United States seventh in quality of workforce); see also Delgado, Chronicle, supra note 1, at 1370, 1377, 1381 (discussing America's economic decline and listing related sources in Appendix A, Part C). 
Hacker, Studs Terkel, and others describe so starkly. ${ }^{31}$ But what about the problem of incentive, of motivation? Wouldn't those im the caregiving sector become lazy and refuse to work hard? Why should they, if they can't be fired, if their business can't ever go under?"

"Mothers are not paid, nor are fathers. Do they take frequent coffee breaks, become lazy and bored?"

"No, of course not. But that's because they have ties of blood. Nature equips them to care. Parents-most parents, anyway-have an instinctual love of their children. Why should anyone love other people's children, or an elderly, incontinent retiree in a nursing home?"

Rodrigo was silent for a moment. "Some people do care about others, even in our dog-eat-dog system which values competition and success above everything else. My approach would enable these people to do what they are inclined to do naturally - help others. As things now stand, those who go to work for Legal Aid, the public defender, or do social work with the inner-city poor, become demoralized. ${ }^{32}$ Society does not value their work. They are underpaid in relation to what they do-which often exceeds in importance that which a Madison Avenue advertising specialist does in a lifetime of getting people hooked on cigarettes or consumerism." 33

"But, Rodrigo, if changing bedpans in a nursing home were highly valued, wages would not be what they are. People have little taste for that kind of work. Much of it is so simple, anyone can do it. That's why it's not highly recompensed. Aren't you trying to distort the market, and isn't that always mefficient, as our friends in the law-and-economics moveinent put it, and, therefore, a bad idea?"34

"Good point," Rodrigo conceded. "But tastes are created. They come from somewhere. The same is true of distastes. ${ }^{35}$ People shy away from lielping professions because they're taught those professions are low

31. Hacker, supra note 10, at xiii; Studs Terkel, RaCE: How Blacks and Whites Think AND Feel ABout the AMERICAN OBsession (1992) (arguing that the clock has turned back on the progress of the 1960 s and that once again hostility, resentment, and racial conflict threaten to divide the nation); see also BELL, NOT SAVED, supra note 1, at 10 (acknowledging that the differing self-interest of Blacks and Whites can work to undermine already fragile legal guarantees of equality). See generally Patricia Williams, THE AlChEMY of RACE AND RIGHTS (1991) (detailing traditional legal thinking's inability to cope with the reality of racial relations).

32. See generally James M. Doyle, "It's The Third World Down Therel": The Colonialist Vocation and American Criminal Justice, 27 HARv. C.R.-C.I. L. REV. 71 (1992) (offering harrowing description of lives of prosecutors, police, public defenders, and others charged with servicing the nation's courts).

33. See Richard Delgado, Shadowboxing: An Essay on Power, 77 CoRnell L. Rev. 813, 821 \& n.61 (discussing tobacco company pressure tactics).

34. For a similar argument that antidiscrimination laws distort the inarket, sec EPSTEIN, supro note 1 , at $24-27$.

35. On the reciprocal relation between culture and inedia depiction in creating "tastes," see Richard Delgado \& Jcan Stefancic, Images of the Outsider in American Law and Culture, 77 CORNELl L. REV. 1258 (1992). 
status. Consider your own students, for example. Don't many of them come to law school imbued with idealism, ready to change the world, to represent the poor and the underdogs?"36

"Yes, of course. You're like that now, for some reason."

Rodrigo shrugged off the compliment. "And what happens to them over time?"

"You know as well as I do. They change. Law school depicts corporate law, big-firm practice as the best, and criminal and poverty law as not nearly so prestigious or challenging. After a year or two, most of the ones who began certain that they wanted to vindicate justice and defend the outcasts start to think of law as a technical game. ${ }^{37}$ And the game is more enjoyable when played in a large firm with secretaries, paralegals, Xerox and fax inachines-and, of course, a high salary." 38

"So, every year you see first hand, Professor, that tastes and distastes change?"

"Unfortunately so."

"Could not the pattern be reversed? What if law school painted poverty practice as the best, and big-firm practice as repetitious, sterile, inechamical, and lacking in any serious intellectual content?"

"A few of my colleagues will actually say that in unguarded inoments," I said. ${ }^{39}$ "If they preached it to the students as consistently as they preach the opposite message, we might get a better balance annong our graduates going into each of the different worlds of practice."

"My point exactly," Rodrigo said quietly.

"Rodrigo, I'm trying to think of all the objections your plan would face so that you'll be prepared. Here's one: let's suppose you are right that care is best given by someone whose temperament, training, and job description incline him or her to treat the cared-for person individually, without rush or haste."

"Just the opposite of the factory system, in other words," Rodrigo interjected.

"Yes. And let's concede also that none of us knows whether he or she will need that kind of care later in life. Why does it follow that we should therefore socialize the entire caregiving industry? That goes

36. Robert V. Stover, Making It and Breaking It: The Fate of Public INTERest COMMITMENT During Law School 2 (1989); Terry Carter, Why Students Lose Their Interest in Entering Public Interest Work, NAT'L L.J., July 31, 1989, at 4.

37. See STOVER, supra note 36 , at 20-22, 64 (describing how students interested in public interest become swayed by "brain-testing" challenges in corporate work).

38. See id. at $\mathbf{1 7 - 2 5}$ (reporting survey data indicating that law students become increasingly concerned with obtaining a "comfortable" job).

39. E.g., Duncan Kennedy, Legal Education as Training for Hierarchy, in THE Politics of LAW: A PROGRESSIVE CRITIQUE 40, 52 (David Kairys ed., 1982) (characterizing large-firm practice as far less interesting and demanding than public interest work). 
against our national grain. ${ }^{40}$ And you must admit it might lead to a certain anount of sandbagging by halfhearted caregivers who are attracted to the helping professions because of the imcreased salary and prestige that will go along with them. Would not a better solution be to encourage persons to purchase private insurance? If someone feels he or she is likely to need a nursing home, or if young newlyweds think they may have children who may need child care, etc., why not let thein protect against those contingencies by buying insurance?"41

"Then, if the need arose, they could use the insurance proceeds to buy care-is that the idea, Professor?"

"Something like that. I'm just trying to anticipate what they might say."

"You can't buy love," said Rodrigo levelly.

I couldn't beheve what I had just heard, and wondered if Rodrigo knew he was echoing a line from a well-known Beatles song. ${ }^{42}$ In a moinent, I learned the answer.

"It's trite, but true. Marriages based on money fall apart. Primates separated from their mothers by a glass wall die or fail to grow, even if they are fed and warmed adequately. ${ }^{43}$ Patients even in well-run nursing hoines die sooner than ones who stay at home. ${ }^{44}$ And look at the crime and delinquency rate anong the children our society currently neglects. ${ }^{45}$ The conservatives are right-you can't solve a problem by throwing money at it. ${ }^{46}$ But if you address it with care and concern, often you can. Yet in our society, overbalanced toward production values, there is not enough care and love to go around."

"Perhaps volunteerism is the answer, as the Republicans say," I suggested. ${ }^{47}$

"That only goes so far," Rodrigo rephed. "Our communal, loving

40. For a statement of libertarian and classical welfare capitalist positions, respectively, vis-àvis social regulation, see generally EPSTEIN, supra note 1; SMITH, supra note 4.

41. See Richard Posner, Economic ANAL ysis of LAw $91-96$ (3d ed. 1986) (discussing role of insurance in providing against future costs).

42. The Beatles, Can't Buy Me Love, on A HaRd Day's Night (Electra Records 1964).

43. Herman Dienske \& Rochelle Griffin, Abnormal Behaviour Patterns Developing in Chimpanzee Infants During Nursery Care-A Note, 19 J. Child Psychol. \& Psychiatry 387 (1978).

44. E.g., Jerry Carroll, Your Money and Your Life, S.F. ChroN., June 18, 1992, at D3, D6 (relating plight of patient with Lou Gelurig's disease whose family could no longer afford home care but refused to put lim in a facility where, despite the good care, all the patients die within one ycar).

45. E.g., HACKER, supra note 10, at 179-98 (discussing "Black crime" and citing statistics showing insufficient police response to proportionally ligher number of Black victims of crime).

46. See, e.g., Charles MURRAY, Losing Ground (1984) (arguing that social welfare programs have failed completely); THOMAS SowELI, CIVIL RIGHTS: RHETORIC OR REALITY? 8690 (1984) (arguing that earmarked subsidies inay principally create White resentment while failing to resolve deeper problems of economic exclusiou).

47. Jason DeParle, "Thousand Points" as a Cottage Industry, N.Y. Times, May 29, 1991, at A1 (discussing the implementation of the Bush Adninistration's call for renewed commitment to volunteerism through the Points of Liglit program). 
instincts have atrophied froin disuse. We are too caught up in a linear, production-oriented mentality. ${ }^{48}$ Not to demean it-it was highly useful during the period of coloinal and industrial expansion. ${ }^{49}$ But now our needs are more diverse, yet we are equipped with all the wrong impulses." balance."

"And I suppose you think other societies have struck a better

"Actually, yes," said Rodrigo, looking shightly uncomfortable. "Although to be truthful, some of them have gone overboard in the other direction, have sacrificed efficiency and productivity for a rather sinarmy form of social life based on connection and-what do you call it? Good vibes."

I wondered if Rodrigo might be referring to countries associated with his own ethnic background and heritage. But noticing his discomfort, I decided not to press him too closely.

"I commend you for your honesty. I agree that there is often an inverse relationship between the two faculties. The inore productive a society becomes, the more stunted they tend to be in love, affection, spontaneity. But if a culture goes all out for love, emotion, develops its affective side too inuch, it may pay a price im efficiency or productivity. What you're saying, then, is that we have to keep them in balance-right?"

"Not quite. The idea is to relegate activities that he on the caregiving side to intelligent socialist treatment, and ones on the productive side to aggressive laissez faire capitalism. Withni each sphere, it's fine to be as unbalanced as one wants. The capitalists in my ideal society could be aggressive and even devoid of human feelings-so long as they did not break the law or interfere with what the more nurturing caregivers were doing on the other side. And so similarly with the caregivers. Oh-and by the way, Professor. To answer your question about sandbagging: Any caregiver caught doing substandard or halfhearted work would simply be fired and sent over to the private sector." efficient?"

"And you think that a society run along those hines would be

"Yes, for two reasons. First there would be a decided trickle-up effect. $^{50}$ A vibrant and well-funded helping sector would turn out able workers and reduce the number of delinquents and welfare drags. And the productive sector, realizing it can sell commodities to the caregiving

48. I recalled our earlier conversation on this very point. Delgado, Chronicle, supra note 1, at 1369-73.

49. Id. at $1370-73$.

50. I was intrigued by Rodrigo's reversal. In supply-side economics, of course, the "trickledown" theory was used to justify deregulation, tax incentives, and other measures the Republicans instituted to stimulate production, and to benefit capitalists and investors. In theory, the improvements such measures would bring the economy in general would filter down to the poor and underemployed. 
sector-because that sector is now well-financed-would invest heavily in 'human capital,' thereby developing powerful new domestic markets it does not have now. ${ }^{51}$ And by the way, Professor, yes, I do think that Hispanic and Black populations have done a better job at providing care, certainly for their dependent elderly, and probably for children and the mentally ill as well. ${ }^{52}$ Your Saxon friends, with all their production expertise, could well look to these sources for models."

"But I thought that you said earlier that all one would need to do is put out the call and thousands of talented schoolteachers, childcare workers, and the like would come surging forward."

"Some would. But they might need lessons in how to do it."

"Kind of a reverse Peace Corps."

"Something like that," Rodrigo said. "We talked a httle about these things before."

"I remember. ${ }^{53}$ Give ine a second while I throw this out. Want another cup?" Rodrigo shook his head no, and I carried the coffeemaker and pot to the sink outside, where I deposited the grounds and now thick coffee. As I walked back, I reminded myself to ask Rodrigo about the matter that had brought him to my office in the first place.

When I returned, Rodrigo was leafing through the book on iny desk, Andrew Hacker's Two Nations. I remembered that he had been reading it, too, and so seized on this to ask him about the matter that had been on my mind: "Rodrigo, I sense we're nearly finished talking about your paper-the first version, I mean. Now I'd like to find out why you have to revise it for your professor. But first, tell ine a little more about the prize. How much did you win? Did you get to make a trip to receive your award?"

"Two hundred fifty dollars, but no trip. They sent ine the certificate, the check, and a ince award letter by inail. None of this did me much good with my instructor, however. When I told him about the prize, he hardly blinked. He was having appointments with each of his students, one every fifteen minutes. He had a sheet of notes on each draft. The inain gist of mine was that this was an interesting idea, but a hittle unfocused. He urged ine to concentrate on the problems of innercity Blacks. I'm supposed to write up what the ideal civil rights policy would be-'if any,' he said."

"And so, does he want you to build on your insight about socialisin and capitalism?"

51. See, e.g., Delgado, supra note 17, at 1840-45 (suggesting that conservatives have an incentive to invest im human capital of non-Whites so that the latter can become participants in economic exchange).

52. See supra note 14 and accompanying text.

53. Delgado, Chronicle, supra note 1, at 1375-76 (Rodrigo discusses how Whites should allow non-Whites into the fold, if only for reasons of self-interest). 
'I think that's pretty much up to me, but I'm thinking of doing it if I can. There's actually a second essay competition I can enter if I write fast. It's entitled, 'A Civil Rights Policy for the '90s and Beyond,' and is sponsored by a conservative organization. But they make clear that there are no ideological restrictions. Liberals and folks like me are free to apply," Rodrigo said smiling at his own joke. "Since it would be a more or less completely revised paper, I'm pretty sure I could submit it."

"You might check with them first," I suggested. "Best to avoid any hint of scandal. Conservatives can get righteous about the darndest things."

"Maybe I'll disclose in a footnote low this essay builds on the previous one."

"That should do it," I said. "But before getting into this one, tell me: were you disappointed when your Professor asked you to restructure your article?"

"No, not really," Rodrigo replied cheerfully. "He's a good teacher, even if he didn't warm up to my paper. I think his mimdset was that I was going to write about civil riglits. It's natural on his part, given who I ain. And it's possible I gave him that impression wlien we inet for our mitial conference early im the semester. I don't really mind. It's an opportunity to look at soine things I've always wanted to read."

I inarvelled once again at Rodrigo's good nature in the face of what soine would have seen as insufferable paternalism on the part of his professor.

As thougl reading my mind, Rodrigo interjected: "You could see his reaction as an instantiation of the very mechainsm I wrote about in the first paper: corruption of taste, disdain for anything smacking of social service. ${ }^{54}$ Civil rights has an urgent, social-engineering ring to some members of society's elites. Maybe the professor unconsciously thouglit all my talk about love, caregiving, and compassion was 'soft,' and that a paper focusing on eliminating glietto crime would be inore like it."

"Who knows?" I said as noncoinmittally as possible, not wanting to be too harsli on a fellow faculty meinber. "Tell me your thoughts on revising the paper. Do I get a cut if you win another prize?"

"How about dinner?"

"You're on. Now let's hear wliat you are tlinking of saying."

54. See supra text accompanying notes 6-9. 
II

\section{In Which Rodrigo Attempts to Solve the Problems OF 'His PeOPLE'}

"I'm thinking of linking the new paper to the general theory I outlined in the first one."

"I'm not sure what you mean. I hope you're not going to maintain that all ghetto kids need is a little love."

"Not at all," Rodrigo rephed, a hittle sharply. "Although love does have something to do with it. You see, I think your country-I mean, our country-has its civil rights policy exactly reversed. In terms of the structure I laid out earher, I mean. We shower love, affection, and indulgent treatment on minority group members who least need it-the middle-class, well-trained, and imtellectually able."ss

"I can definitely think of a few cases," I rephed. "In fact, I've written about that myself." 56

"So we adulate and grease the skids for talented professionals of color-those who would have succeeded without that anyway. And we tell the rest to lift themselves by their bootstraps, get a job, stop being welfare leeches, and so on. ${ }^{57}$ We turn a cold shoulder to those who need individualized care and concern, implying that they should take their chances-nil, if the truth were known-in the free market. ${ }^{58}$ And we hold close to our bosoms those who are most like us-who do not need the embrace. Blacks at the bottom of the heap get little personalized treatment, unless, of course, they commit crimes. ${ }^{59}$ We exclude them

55. I thought of the adulation and affection that Republicans and others shower on certain Black "Horatio Algers," like Clarence Thomas. See also the sharp and sometimes poignant observations of Stephen Carter in his book, STEPHEN CARTER, REFlections of AN AFFiRMATIVE ACTION BABY (1991) (argning that affirmative action must return to its simpler roots, to provide educational opportunities for those who might not have them, and that the beneficiaries of affirmative action must thereafter be held to the same standards as anyone else).

56. For examples of Critical writing on this issue, sec BELL, Not SAVED, supra note 1, at 48 (noting that affirmative action programs are not designed to help lower-class Blacks); Richard Delgado, Affirmative Action as a Majoritarian Device: Or, Do You Really Want to Be a Role Model?, 89 MICH. L. REV. 1222, 1223-24 (1991) (affirmative action assures that "the right small number" of women and minorities are hired).

57. See, e.g., EPSTEIN, supra note 1, at 259-66 (arguing that the best way for lower-educated Blacks to compete in the job market is to offer their services at lower wages); MURRAY, supra note 46, at 39-40 (arguing that White moral confusion about the course of the civil rights movement allowed the blame for poverty to shift from the poor onto the system and history).

58. See EPSTEIN, supra note 1, at 9 (argning that competitive markets offer better and more certain protection against invidious discrimination than any anti-discrimination law); MURRAY, supra note 46, at 223 (calling for the repcal of legislation and legal precedent advocating or rewarding differential treatunent according to race); SowELL, supra note 46, at 112-17 (argning that market mechanisms will ultimately reward private parties who hire and pay for cheaper labor froin underrepresented minorities or women).

59. For discussion of society's great concern over Black criminality, see HACKER, supra note 10, at 179-88. For a treatment of the Black community's ambivalence over its own offenders, see Regina Austin, "The Black Community," Its Lawbreakers, and a Politics of Identification, 65 S. CAL. L. REV. 1769 (1992). 
from our consciousness as much as possible, while those who are bright, well-educated, and able we fawn over and promote."

"Like you."

"That remains to be seen. I'm going on the teaching market this winter-if I ever get my paper done, that is." $" 60$

"It sounds like you have it well $\mathrm{m}$ hand. But tell me, what's your solution to the problem you've just identified? Your professor, like most White people, will want to know not just what's wrong with our civil rights approach, but how to fix it. Do you want to bring back massive social prograins like in the sixties?"61

"It will take a major national effort," Rodrigo conceded. "But it will require both targeting the poor of color with individual care and concern and integrating them into the economy. The essence of being a colonized people is to be both beyond love and excluded from the main avenues of economic well-being." 62

"I've read that literature. But the American race problem is different somehow," I said. "And harder."

"It is indeed," Rodrigo agreed. "I'm thinking of calling it the problem of being Beyond Love."

"Beyond Love?"

"Yes. And if you'll give me a second to call my roommate, I'll tell you what I mean. May I borrow your phone? We were going to go out for dinner, but I need some more time with you. This is helping ine get my thoughts in order. You're a good histener-I like the way you push me."

I gestured toward the telephone, then picked up Hacker's book from my desk. I had been reading it avidly as a welcoine relief from the raft of books written by conservatives which I had read in preparation for the Economics-of-Race meeting.

"Don't leave," said Rodrigo. "This will just take a minute. It has something to do with the subject of that very book."

As promised, Rodrigo's phone call was brief. I was intrigued to learn that his roommate was nained 'Giannina.'

60. So he's really going to do it, I thought. See Delgado, Chronicle, supra note 1, at 1361-64, where Rodrigo first seeks me out, during a visit from Italy, to discuss his prospects for an LL.M. degree and for getting a law teaching job later. I wondered how the irrepressible Rodrigo would fare at the hiring convention and resolved to stay in touch with him during the winter season.

61. For pungent commentary on these programs froin conservative scholars, see generally EPSTEIN, supra note 1; MURRAY, supra note 46.

62. For examples or discussion of this anticolonialist writing, see generally FRANTZ FANON, THE WRETCHED OF THE EARTH (1963) (discussing decolonization and the process of national liberation); Albert Memmi, The Colonizer AND THE Colonized (Howard Greenfeld trans., 1965); Doyle, supra note 32 (comparing role of White men in criminal justice system to that of White colonial administrators and commissioners). 


\section{A. "Beyond Love": In Which Rodrigo Explains What Stands in the Way of Our National Civil Rights Policy}

"There," said Rodrigo, putting down the phone. "We're all set for later. How much of that book have you read?"

"I'm just finishing. It presents a pretty dismal picture. Before starting, I sneaked a look at the conclusion to see if the author makes a grand proposal, offers any sort of hope or 'quick fix' at the end. Nothing that I could see. ${ }^{63}$ So your work is definitely cut out for you."

"The main task, as I see it, is to deal with the problem of Blacks being, as I call it, 'Beyond Love.' For the vast majority, our society is - prepared to offer neither entrée into the economic system nor love and concern. They are excluded both from the economy and from networks of love."

"So the program of enhanced, synergistic, and reinvigorated spheres of love and economic development which you outlined earker would leave them out-i.e., unbenefitted."

"I'm afraid so. Something more is required."

"I agree. I and others have written that our current system of White-over-Black ascendancy is far from accidental. ${ }^{64}$ It benefits Whites; indeed, one can see our entire current system of civil rights laws and policies as a sort of homeostat, assuring that the system has exactly the right amount of racisin. ${ }^{65}$ Not too much, for that would be destabihizing, nor too hittle, for that would cause Whites to forfeit important psychic and pecuniary advantages. We have written about interest-convergence, and the way in which periodic ringing 'victories,' like Brown $v$. Board of Education, end up benefitting Whites more than Blacks, legitimize a basically unfair systein, and, when they become too imconvement, are smiply cut back by narrow judicial construction, administrative footdragging, or delay."

"I've read that work and agree with it," Rodrigo said quietly. "I hope to build on it. The trick is to offer a solution that recognizes and

63. HACKER, supra note 10, at 215-19; see also id. at xiii ("The reader should be advised not to expect this book to end on an optimistic note.").

64. See, e.g., Bell, Not SAVEd, supra note 1, at 3-7, 26-74, 123-61; Derrick A. Bell, Jr., Brown v. Board of Education and the Interest-Convergence Dilemma, 93 HARV. L. REV. 518, 522-28 (1980) (discussing maintenance of segregated schools as important to poorer Whites who had expectation that their social status would remain superior to Blacks'); Richard Delgado, Derrick Bell and the Ideology of Law Reform: Will We Ever Be Saved?, 97 YALE L.J. 923 (1988) (reviewing Bell's Chronicles and the history and effects of racism through the words of Bell's alter ego, Geneva Crenshaw).

65. See Delgado, supra note 56, at 1224.

66. See, eg., BELL, Not SAVED, supra note 1, at 51-122 (discussing benefits to Whites of civil rights litigation); Bell, supra note 64, at 526-32 (discussing ways in which southern states and cities, as well as the Supreme Court itself, limited or impeded the implementation of the principles of Brown); Delgado, supra note 64, at 925 \& n.9, 926 (summarizing Beil's behef that "American racism is here to stay in our most prized legal institutions despite our most exalted legal rhetoric"). 
takes into account the interest-maintaining, homeostatic element of our current approaches to race."

"If you pull that off, I'll nominate you for a second Nobel Prize," I said-then immediately regretted it when Rodrigo shot ine an appraising look.

"I'n sorry," I said. "I'm on your side. The search for a solution is urgent and important. I'in just a battle-scarred veteran of inany defeats. Don't let my jadedness put you off. It's an occupational hazard. ${ }^{67}$ Please continue."

As I had hoped, Rodrigo brightened up. 'I'n glad. With the change in Administration, there may be a window of opportunity for new approaches, ones that may actually do some good." He paused for a moment, then continued:

"Have you noticed, Professor, how few animals kill members of their own species?"

"I have. Although you should know soine sociobiologists are pointing out exceptions. Jane Goodall has shown that the great apes, for example, do soinetimes war against and kill each other."68

'I didn't mean to inake a universal point. But there's some truth in the generalization, don't you think?"

"Yes, of course. And if you mean to apply it to human beings, I suppose it's a valid starting point. We rarely go to war against those whoin we see as closely related by blood and tradition. It's easier to demonize and kill ineinbers of that other tribe or clan or nation."

"And might not something like that account for our racial predicainent? Society has inarginalized and excluded African-Americans from the beginning, rendered thein the Other in so inany settings that even after the enactinent of civil rights laws, most Americans cannot think of thein as their equals. Hacker points this out as forcefully as anyone. ${ }^{70}$ Blacks, especially the Black poor, have so few chances, so little interaction with inajority society, that they might as well be exiles, outcasts, permanent black sheep who will never be permitted into the family. ${ }^{71}$ Majority society has, in effect, written them off. We inight as well erect

67. See Alan Freeman, Race and Class: The Dilemma of Liberal Reform, 90 YaLE L.J. 1880, 1885-86 (1981) (implying that the despairing tone of some Critical Race Theory writing may discourage some idealistic readers from pursuing civil rights work).

68. Jane Goodall, The Chimpanzees of Gombe: Patterns of Behavior 530-34 (1986); see also Lionel Tiger, Love and Murder Among the Chimps, N.Y. TIMES, Mar. 13, 1988, $\$ 7$, at 14 (reviewing Michael P. Ghiglier1, EAST OF THE MOUNTAins OF THE MOON (1988) and recounting Ghighieri's observations of aggressive and often murderous behavior by male chimps asserting territorial rights or usurping the role of other male chimps).

69. E.g. Jerome Grossman, With a Demonized Enemy, Going Nuclear Seems Easy, L.A. TIMES, Aug. 13, 1991, at B7 (citing poll in which $45 \%$ of Americans surveyed favored use of nuclear weapons against Iraq during beginning of Gulf War to save U.S. lives).

70. HACKER, supra note 10 , at 7,14 .

71. Id. passim. 
walls around their communities-as a few neighborhoods have tried to do." 72

"I remember some of Hacker's figures."

"The man wields numbers and statistics the way a classical composer wields notes and instruments. His voice is calm and temperate. But the picture he renders is devastating. Fully eighty percent of Black students in New York attend segregated schools, as do inore than half in many other states: ${ }^{73}$ Even in schools that are integrated, Black and Brown students comprise a majority of the slow-learner tracks, so that ostensibly desegregated schools really consist of White and non-White classrooms within the same building. ${ }^{74}$ Affirmative action has helped inany White women and a few middle and professional class Blacks. ${ }^{75}$ But Blacks, especially Black men, have made few gains in the job market. During the 1980s, the income of Black inen rose only from $\$ 715$ per $\$ 1000$ of White income to $\$ 716$ per $\$ 1000 .^{76}$ The few Black families that have made it to middle class status, defined by a family incoine of $\$ 50,000$ or more, generally have two earners. ${ }^{77}$ A White family inaking over that amount is three or four times more likely than a Black family to have a single earner, usually a husband making $\$ 75,000$, and a nonworking spouse. ${ }^{78}$ The typical Black middle class family is inore likely to consist of a male bus driver earning $\$ 32,000$ while his wife brings in $\$ 28,000$ as a teacher or a nurse. ${ }^{79}$ There are inany Black nurses, but few dental hygiemists." ${ }^{80}$ Rodrigo picked up Hacker's book and read aloud, "While White patients seein willing to be cared for by Black nurses, they apparently draw the line at having black fingers in their mouths." 81

"Of course, our conservative and neoliberal friends will concede these dismal statistics, but maintain that they are the fanlt of welfare dependency or a culture of poverty," 82 I asserted.

72. E.g., City of Memphis v. Greene, 451 U.S. 100 (1981) (addressing a street closing which effeetively curtailed traffic into an all-White community).

73. HACKeR, supra note 10, at 162-63. "The National School Board Association measures segregation by computing the number of Black youngsters in a state or locality who are enrolled in schools where they, or Hispanics, make up a majority of the pupils." Id. at 162.

74. Id. at 164-65.

75. Id. at 132 .

76. Id. at 101 .

77. Id. at 98-99; see also id. at 115 (percentage of woinen working is inuch higher among Blacks than Whites).

78. Id. at 99.

79. Id. at $98-99$.

80. Id. at $110-11$.

81. Id. at 110 .

82. E.g., Oscar Lewis, The Culture of Poverty, in ON UNDERSTANDING PoverTY: Perspectives from the Social Sciences 187 (Damiel P. Moynihan ed., 1969) (describing the culture of poverty and its effects); see also NATHAN GLazer \& DANIEL P. MOYNIHAN, BeYoND the Melting Pot: The Negroes, Puerto Ricans, Jews, Italians, ANd Irish of New York CITY lxxxvi-lxxxvii (2d ed. 1970) (discussing welfare dependency as exacerbating probleins of racism); MURRAY, supra note 46, at 18-20, 38-40 (discussing White resentinent of the perceived 
"Hacker has an answer to that," Rodrigo retorted. Blacks live in deteriorated neigliborlioods, suffer debilitating diseases, live shorter lives, and commit crimes in far greater frequency than do Whites. ${ }^{83}$ In a few cases, these may be the products of individual choice, laziness, or inertia. But when large numbers of people live this way, the suspicion arises that social forces are responsible. And Hacker says he knows what the forces are: White racisin and neglect. Whites, who loold all the cards, simply are unwilling to perimit Blacks to achieve equality with them."84

"What about Blacks who achieve wealth and fame? Soine do."

"Most are in sports and entertainment, or else on TV. ${ }^{85}$ As Hacker points out, the average young Black gang member, if lie watched TV at all, would be amazed at the number of cardigan-wearing Black doctors and lawyers that appear there-all out of proportion to their numbers in real life." 86

"But don't inost Black criminals prey on Black victims?" I asked.

"Of course. But it's Black-on-White crime that society finds terrifying. ${ }^{87}$ Blacks liave a three-times greater cliance of dying from a policeInan's bullet than do Whites. ${ }^{88}$ The prisons are nearly one-half Black. ${ }^{89}$ And inurderers who kill Whites are ten times more likely to receive the death sentence than ones who kill Blacks."90

"His statistics certainly help you establish your case. As a group, African-Americans live in a condition of near-apartheid. ${ }^{91}$ Yet few Whites will accept any responsibility for our deplorable condition. ${ }^{92}$ We're as far removed froin national consciousness as I can ever remember. Every one of our needs is on the back burner. It is even perinissible, if not fashionable, to blame Blacks for their predicament, to view us as the aggressors, to see us as opportunistic whiners who do not want to

permanency of welfare to Blacks and the failure of helping-hand training programs); SowELL, supra note 46, at 77-90 (arguing that cultural differences, rather than skin color, determine economic status).

83. HACKER, supra note 10 , at $35-38$.

84. See id. at 14,217 (Whites continue to believe in their own superiority and suspect Blacks of inferiority).

85. Id. at 107 (citing the examples of Bill Cosby, Bryant Gunibel, Magic Johnson, Mike Tyson, and Oprah Winfrey).

86. Id. at 40.

87. See id. at 179-80 (discussing George Bush's use of Willie Horton in his advertisements and speeches during the 1988 presidential campaigu).

88. Id. at 189.

89. Id. at $180,197$.

90. Id. at $191 \mathrm{n.*}$. Moreover, even holding other factors "such as the ferocity of the crime and the social status of the viction ... constant, the prospect for the death penalty was still four times higher than when the victim was white." Id.

91. Id. at 4; see also supra text accompanying notes 73-90.

92. See HACKER, supra note 10, at 60 ("[W] everyday reality: that to be black is to be consigned to the inargins of American life." $)$; id. at 218 ("[W] hite America ... has made being black so disconsolate an estate."). 
work."93

"I'm rapidly getting that sense," replied Rodrigo, "both from things I read and from the reinarks of my fellow students in class. It's been a revelation. Where I came from, I was hittle more than a curiosity for my skin color. Here, it's practically a badge of identification-although I inust confess that a few Whites and a professor or two have taken a great interest in ine and my ideas. As have you."

"But, of course, I'm a man of color."

"True. Although you nnove in a White world. I hope to be like you one day."

"First things first. You need to finish this paper. And what a dilemma you've painted. Black people are desperate, poor, deinoralized, and confined to inferior schools and all-Black neighborhoods. ${ }^{94}$ As soon as a neighborhood becoines more than about eight percent Black, all the Whites start to leave. ${ }^{95}$ What does your scheme for adjusting love and production have to say about that?"

Rodrigo leaned forward. "We need botli a new mytl and a form of coercion." I sensed that he had thought about this, but he seemed inore tentative now than before. So I said encouragingly:

"I love to hear about inytlis. I write about narratives and stories myself, and believe this is a fruitful line of scholarship. ${ }^{96}$ I'd like to hear what you mean by coercion, too."

Rodrigo began: "I'In sure you know about Hobbes and his behef in a commonwealth created through mutual covenants?"97

I nodded, so he went on: "It's a powerful image, not so inucl because it's true in any hteral sense-no one inakes explicit promises when they are boru into the human commumity-but because of its mythic significance. People in the majority group know that if all, or most of thein, obey the law, everyone will be better off. And so tliey pay their taxes even if they could cheat, they stop at red lights in the middle of the might when no one is watching, and so on. The Rule of Law prevails because everyone knows that if we all adhere to society's rules and regulations, we will all benefit. Otlierwise, we could decline into sav-

93. Id. at $50-52$.

94. See supra text accompanying notes 76,83 .

95. HACKER, supra note 10 , at 36 .

96. See Richard Delgado, Storytelling for Oppositionists and Others: A Plea for Narrative, 87 MiCH. L. REv. 2411 (1989) (arguing that the use of stories can be helpful in the struggle for racial reform because it shatters complacency and challenges the status quo); see also BELL, Nor SAVED, supra note I (reciting 10 metaphorical tales to discuss the experiences of Blacks in America and their struggle for racial equality); Kathryn Abrams, Hearing the Call of Stories, 79 CALIF. L. REv. 971 (1992) (arguing that the emergence of feminist narrative scholarship is a distinctive form of critical legal discourse).

97. Thomas Hobbes, Leviathan 112-19, 172 (Herbert Schneider ed., The Liberal Arts Press, Inc. 1958) (1651). 
agery, and it would be every person for himself or herself."98

'What about the 'free rider' or sociopath who discovers that he or she can gain an edge simply by disobeying the law?"99

"A few do that," Rodrigo rephed, "but the myth discourages them by designating them bad. They know that if they're caught, they will earn everyone's disapproval."

"If not be prosecuted criminally," I added.

"That's where coercion comes in-for those who are not adequately socialized in the myth, or who simply succumb to temptation."

"And I gather you're saying that the social compact and the force of law are inadequate to protect minority people-to enforce and gnarantee the success of our civil rights laws and policies?"

"Precisely. Would you like me to spell it out a little more, Professor?"

"I'in still going strong," I rephed-even though I was definitely feeling the late hour and fast pace. "And it is iny line of work. I hope we're not going to inake you late for your dinner appoimtment."

"Giannina said it's okay, but only on condition that I agree to introduce her to you soineday. She admires your work enormously."

"Is she a law student like you?"

"I'll let her explain that when you ineet her. Perhaps we'll have you over when the term finishes."

"I'd be dehighted," I said. "But tell me more about inyths and coercion."

Rodrigo glanced over at the Hacker book on my desk, then contimued.

\section{B. In Which Rodrigo Explains the New Civil Rights Myth and Form of Coercion}

"The basic problem, as your own work suggests, Professor, is that Blacks lie outside the social compact. ${ }^{100}$ We are, as I call it, Beyond Love. The majority group has fignred out that they don't need us, that it's more profitable to keep us as a ready supply of menial workers and a source of psychic consolation for blue collar, working class Whites. Outside these uses, we are surplus, annoyances, of concern only insofar

98. Id. at 107 (life in a state of nature would be "solitary, poor, nasty, brutish and short").

99. E.g., Garrett Hardin, The Tragedy of the Commons, 162 ScIENCE 1243 (1968) (discussing predicament of society in which a few members attempt to gain an edge by abusing the common trust).

100. Richard Delgado \& Jean Stefanic, Derrick Bell and the Chronicle of the Space Traders: Would the U.S. Sacrifice People of Color if the Price Were Right?, 62 U. Colo. L. REv. 321 (1991) (agreeing with the plausibility of Derrick Bell's parable in which the United States sells all its Afriean-Americans for solutions to its probleins); see also DERRICK BELL, RACE, RACISM, AND AMERICAN LAW 1-51 (2d ed. 1980) (recounting a history of Blacks in the United States in which they were given the roles of "sacrifice" and "supergoats"). 
as we impinge on society through the occasional violent crime, or have babies, thus increasing the tax burden. They are prepared to write us off, eliminate us from their concern, to accept hittle from us so long as we deinand little in return."101

"Some of them are calling for concern, for attention to our needs." 102

"But they are voices in the wilderness. The average middle class White, according to Hacker, knows and cares for no Blacks, has none hiving in his or her neighborhood, has his or her children attend schools where few if any of us attend-and is quite satisfied with that state of affairs." 103

"A bleak indictment," I mused. "But you said you had a solution of soine sort."

"More like an approach, inore like what one would do if one desired to change things. But of course I admit, as you've written, that any desire to better our dire estate may be missing from society today."

"That may change. There is a new Administration. Given this, what would you do?"'

"I would disseminate a new myth. The current one does not work for us. With ordimary laws, White folks know that if everyone follows thein, we will all be better off. ${ }^{104}$ But with civil rights, the situation is exactly the reverse."

"Racisin benefits Whites," I chimed in. "They know that as a class they are better off with us marginalized and excluded. ${ }^{105}$ So, they don't take their civil rights obligations that seriously."

"Except for a few tokens needed to legitimate the system. ${ }^{106}$ Most

101. See HACKER, supra note 10, at 4, 90-92, 218 (most White Americans think it is time for Blacks to make it on their own; most White Americans have a poorer opinion of the mostly Black or Hispanic mothers on AFDC than they do of the overwhelmingly White recipients of Social Security).

102. I thought of White colleagues and scholars who were writing helpful analyses of race. E.g., T. Alexander Aleinikoff, The Constitution in Context: The Continuing Significance of Racism, 63 U. CoLo. L. REv. 325 (1992) (arguing that race discrimination against non-Whites reinains a serious problem in American society and that recognition of this bigotry has important implications for the crafting of constitutional doctrine); Alan D. Frecman, Legitimizing Racial Discrimination Through Antidiscrimination Law: A Critical Review of Supreme Court Doctrine, 62 MINN. L. REv. 1049 (1978) (arguing that although the law outlaws racial discrimination, it tolerates conditions that promote the lower economic status of Black Americans); Duncan Kennedy, A Cultural Pluralist Case for Affirmative Action in Legal Academia, 1990 DukE L.J. 705 (arguing for a large expansion of our current commitinent to cultural diversity on the ground that law schools are political institutions); Gary Peller, Race Consciousness, 1990 Duke L.J. 758 (exploring the ideological roots of Critical Race Theory, its reinterpretation of race consciousness, and its break with the dominant civil rights discourse).

103. See supra note 101; see also HACKER, supra note 10, at $37-38$ (Whites prefer to avoid Black neighbors).

104. See supra notes 98-101 and accompanying text.

105. See supra note 100 .

106. Delgado, supra note 56, at 1224. 
of us fall outside the clan. Like a species of wild animal, we are entitled to hittle consideration. It's not that we may be killed at random, but fellow-feeling simply does not extend to us. We are beyond love and concern. Norm-breaking behavior by a member of the majority which breaches the country's professed ideals about brotherhood, equality, and dignity for all confers a benefit on the law breaker and his group. That's why even blatant law breakers, persons who refuse to rent to or hire qualified ones of us, rarely receive any punishment."107

"With ordimary laws, someone who acts in a law-abidimg manner, stopping at a red hight in the imddle of the night, for example, gets to feel good, satisfied, and proud; he beheves himself a good citizen. Are you saying that the same isn't true for people who adhere to the civil rights laws?"

"Yes. The good-citizen myth is inuch weaker, if it exists at all. Enforceinent is infrequent and ineffectual. There are all the well-known excuses. The breach was unintentional. It was justified by a busmess necessity. There was another cause for the rejection. And so on."108

"So we need both a better, or at least a different, inyth, and a new way of enforcing it."

"It's easier to think of what the new form of coercion would be," said Rodrigo. "And I think it inust come froin us, not from them, at least initially. I think it would be some form of what your society calls terrorism or sabotage. We might call it self-help, liberation, or something of the sort. But there would need to be some form of redress for flagrant breaches of equal respect. And it would need to be as swift and effective as the penalties society applies to ordinary lawbreakers."

I shuddered. ${ }^{109}$ "Rodrigo, it's fine for you to discuss these matters with friends like me, in the safety of iny office. But I must urge you in the strongest terms to keep your ideas to yourself." I looked at the door to see if I had closed it after enuptying the coffee; with great rehef I saw I had. 'Italy may be different, but here the very word 'terrorism' raises hackles. I wouldn't be surprised if your advocacy of such tactics did not have something to do with your earlier troubles with the INS." 110

107. E.g., HACKER, supra note 10 , at 35 (despite antidiscrimination housing laws, residential areas remain heavily segregated); see also id. at 191 (Black victims of violent crime are less likely to see justice done).

108. Regarding the loopholes and exceptions that courts have created or engrafted on the civil rights laws, see Richard Delgado, On Taking Back Our Civil Rights Promises: When Equality Doesn't Compute, 1989 Wis. L. REv. 579, 583-84 (1989) (arguing that doctrinal retrenchment is occurring in civil rights eases in order to slow down the use of computers and sophisticated methods of statistical proof to help establish discrimination); see also BELL, NOT SAVED, supra note 1, at $51-75$ (caustic critique of U.S. civil rights policy).

109. Rodrigo had blithely raised these matters before, much to my chagrin. Delgado, Chronicle, supra note 1, at 1377-78 (Rodrigo discusses the use of sabotage and terrorism to quicken the pace of the dominant group's sharing power with minority groups).

110. Id. at 1379 (Rodrigo had been subject to denaturalization by the INS due to his six months 
"Fine," said Rodrigo, seeming not at all abashed by my heated warning. "Although surely the most perceptive among your White friends know that continued neglect can only cause more violence, more frustration, inore uprisings like those in New York and Los Angeles. ${ }^{11}$ I'n inerely pointing out that at soine point, this anger might get channelled."

"A few of us have dared to broach that suggestion. ${ }^{112}$ But unlike you, we have tenure. Perhaps you had better backpedal or at least ghde over the part about coercion, and go on to the part about inyth. White people love inyths. All of us do."

"What's needed is a reason-a plausible and inspiring reason-for expanding our circle of syinpathies to include groups who are now excluded. Group self-interest, likc that which accoinpames paying one's taxes or stopping at red hights, doesn't work because with respect to those excluded groups, the inajority's incentives point the other way. ${ }^{113} \mathrm{We}$ need a reason for caring when caring is costly and does not benefit the caregiver in any obvious way. We need a reason for making a group, now situated outside the social coinpact, a meinber of it. Current antidiscrimination law apphies coercion, ineffectively, to injure the broader group, to deny it benefits, goods it wants. So the myth must take this into account."

"A tall order," I commented dryly.

"True, since with our treatinent of mmorities-in this area alonewhen we break the law we are better off. And the 'free rider,' the deviationist who defiantly breaks the law, who stands up against affirmative action, is cheered as a hero, one who dares to tell the truth, to call a spade a spade." 114

"So to speak." I winced, resolving soinetime to let the innocent Rodrigo in on the meaning of the term. 115 "So, unlike with ordinary laws, one can't appeal to the myth of the social coinpact."

of part-tine military training in the Italian army and possibly due to his advocacy of terrorist tactics).

111. See Synıposium, The Los Angeles Uprising, 56 S. CAL. L. Rev. (forthcoming May 1993).

112. See Austin, supra note 59, at 1816 (if activism within the law fails to reorder priorities and change society, actions outside the law may be required); Robert J. Cottrol \& Raymond T. Diamond, The Second Amendment: Toward an Afro-Americanist Reconsideration, 80 GEO. LJ. 309 (1991) (arguing that society's dismal record of protecting Blacks ought to preclude society froun disarming them).

113. See supra notes $97-101$ and accompanying text.

114. I thought of the hymns of praise from the conservative White cornmunity that greeted the publication of Thomas Sowell, Stephen Carter, Clarence Thomas, and some of Randall Kennedy's works. See also HACRER, supra note 10, at 52 (conservatives turn to Black conservatives like Sowell, Thomas, and Shelby Steele to defend and support their own positions).

115. "Spade" is a disparaging term for an African-American. 16 Oxford ENGL1SH DictionarY 96 (2d ed. 1989) ("A Black Person, a Negro, esp. male: freq. in White use, as a term of contempt or casual reference. Formerly among U.S. Blacks, a very dark-skinned Negro. slang (orig. U.S.).") (Definition 3a). 
"Only weakly, at best. Blacks lie outside society. They are the Other. We refer to thein as 'them,' as 'those people.' Hacker says lying behind this aversion is the sense that African-Americans are an inferior order of being. ${ }^{116}$ This is a White society; they live here at our sufferance. ${ }^{117}$ They mustn't get too close, begin living in our neighborhoods, go to school witl our children, date our women. African-Americans were brought here for their labor, and an attitude-racism-was developed to justify that practice. Slavery was abolished, but the attitude remained, because society still needed Blacks for menial work. ${ }^{118}$ After three centuries of this, it's hardly surprising that the dominant group sees Blacks as outside their circle of friends and families, outside their spliere of concern. There are, of course, national norms of brotlerhood, equality and so on-as a prime example, the fine words of the Declaration of Independence. But these liave little impact. The dreadful conditions of whicl Hacker speaks are not at all upsetting because they are their problem, not ours."119

"And the system works," I added glumly. "Discrimination benefits the dominant group."120

"That's why many White folk cannot be made to see discrimination the way they do the red light. Obeying the civil rights laws does not make them feel particularly good and virtuous. In actimg generously toward a Black, they do not see themselves as building a safer, more colresive cominumity. And the reason is that the Black is not part of their cominumity."

"So the virtue mytli doesn't work. What is your alternative?"

"This is the final part of my paper, and it's a little liard to explain," Rodrigo said. He paused, as though collecting his thoughts.

"Take your time." I leaned back in my cliair and drained the last bit of coffee from iny cup.

"There are actually two parts to my plan. First, the implementation would be put in the liands of "bridge people'121 -those older folks, often themselves marginal but yet working or respectable, who still hive in the neigliborlioods and barrios and liave a degree of contact with the lost kids of the gangs. They miglit be the postal clerk, retired serviceman or porter - people like the 'Mayor of the Block' in the movie Do the Right

116. HACKER, supra note 10 , at $14,26-28$.

117. Id. at 4.

118. Id. at 14 .

119. See id. at 50-64 (arguing that most conservative Americans believe that for at least a generation, Black people have been given plenty of opportunities, so they can only blame themselves for whatever difficulties they face); cf. id. at 217-18 (discussing the American ideal that all mdividuals are expeeted to make it on their own without special dispensation).

120. See supra notes 64-66 and accompanying text.

121. The term is Regina Austin's. See Austin, supra note 59, at 1799-800. 
Thing. ${ }^{122}$ We would give them MacArthurs and large grants and put them in charge of redeeming their own neighborhoods, especially the least lovable residents who hive there-the Black kids im the sweatsuits, tennis shoes, and gang insignia-the ones who terrify Whites, the ones that Whites cannot relate to."

"There is actually a body of einerging writing that says einpathy only goes so far, that we cannot identify with or love anyone who is too different from us, cannot resonate to a 'story' too unlike the one we usually hear. ${ }^{123}$ So your idea of finding bridge people, people who split the gap between the stable, taxpaying White suburbanite and the alienated ghetto kid, makes sense. But where would the money come from? How would you get middle class society to give millions of dollars to bridge people for the benefit of welfare mothers and teenage hoodlums?"124

"That's the other part," Rodrigo said. "We need to persuade them that burdening themselves to reheve anguish among African-Americans benefits thein."

"And how would you do that?"

"We would tell them they should pay because the recipients-people of color-have a secret. The secret is one that they will learn only later, once the programs are in place, and that once disclosed will bring them an incalculable benefit." Rodrigo was speaking softly yet emphatically. "The secret is one they cannot learn until Blacks and other outsiders are brought fully imside, are made equal members of society. They will learn it when they have relaxed the barriers, when they have decided, as a group, that Blacks and Mexicans and gays and lesbians are no longer Beyond Love."

'So, by saying 'I love you,' Whites will receive this benefit, learn this secret?" I wanted to get Rodrigo to clarify his thoughts before he handed in his paper, with its extraordinary thesis, to a skeptical professor at his law school.

"Yes, something like that. And by it I mean learning to love those who are least hike you, those who frighten and put you off. I mean the sixteen-year-old Black youths in joggiug suits and gang paraphernaha, walking in groups of four and looking mean. I mean loving the unlovable, the ones you now think of as the enemy, the Other, the ones least like you."

122. Do THE Right THING (Universal City Studios 1989).

123. See generally Delgado \& Stefancic, supra note 35 (arguing that racist images from earlier times are only viewed as racist today because consciousness has shifted and society has adopted a different narrative); Richard Delgado \& Jean Stefancic, Norms and Narratives: Can Judges Avoid Serious Moral Error?, 69 TEX. L. REv. 1929, 1930 (1991) (arguing that moral error in judging ean arise from the inability to identify with the different life experiences of the judged).

124. All the movement is the other way, I thought, recalling the rhetoric of the last two political campaigns and the raft of conservative writing urging that we leave Blacks to their own devices. See supra notes 4, 41, 46. 
"Whites are pragmatic. They'll want to know what the secret is before they agree to love the unloved, pay to redress centuries of neglect and indifference, remedy the deferred inaintenance that in a thousand ways we have allowed to build up within populations of color."

I was silent a inoinent. Then I blurted out: "Rodrigo, the current situation brings benefits to the inajority group, as you yourself conceded. You can't seriously think they will give them up in return for a vague 'secret' that they might receive at soine undesignated future time. I'n not sure $I$ would go along, and I'm not even White!'

"You give yourself too little credit, Professor. You have already been doing soinething like that-loving those who are least deserving of love." 125

I calmed down, sensing Rodrigo's seriousness. I did not want to deter him froin telling ine inore, from exploring the vein he was following.

"Their own culture supplies a lost of narratives, reasons we could draw on to support the new myth. It would not be so unlike stories they already subscribe to, ones about receiving a benefit by giving. We could tap these narratives to sliow why the current policy that relegates African-Americans to a life Beyond Love is iniquitous and unworthy."

"I liope you're riglit."

"The effort would be redemptive. As society integrates outsiders, achieves unity, so would the individuals engaged in that task. The social lealing would be mirrored by a psychic, individual one."

"Bearing another's burden does sometimes inake one feel ligliterparticularly if it enables the other to do surprising things. And I suppose you think our White friends will know the reward when they liave done enough?"

"Yes," Rodrigo replied. "The benefit will come naturally, in its tinie. You see, I believe that all are innocent at birth. Children come into the world asking only for healtli and care. They begin life helpless. Some become corrupted by circumstances. None clioose the corrupting conditions that society or outside influences create." Rodrigo was speaking witl great animation now. I wondered what recent experiences he miglit liave liad with small clildren, or whether the inysterious 'Giannina' someliow lay behind this near-spiritual tack of his. I liad miagined him to be an atheist or agnostic; I resolved to ask lim sometinie.

He continued: "And some clildren then cliange from innocent beings to THEM, a tragedy both for thein and us. We can perhaps redeem them-and ourselves-by working to reverse the process. In

125. Was I deserving of the compliment? I recalled a number of times when I had been cutting or dismissive of Whites, imcluding a number who were well-meaning. But Rodrigo was speaking with such fervor that I hesitated to interrupt. 
some ways, the greater $\sin$ is ours for having allowed ourselves to become slothful, uncaring, unloving, hedomistic to the point where we think the anguish of the inner cities is 'their problem.' "'

"So, we are the ones in the jogging suits, after all," I said slowly. "We are the ones in need of redeinption."

"A hittle too harsh, Professor. I prefer to think we all wear the same jogging suit, whether we have bought it im a store or stolen it during a riot, whether we are rich or poor, Black or White."

Something inade me glance suddenly at my watch. "Rodrigo, this reminds me-I have a date to go jogging with Professor Abercrombie in the Park in five minutes. Fascinating as all this is, I'm afraid I must break it off. Wonld you like to join us?"

"Thanks, Professor, but Giannina is waiting for ine. I'd better take off. So, you think iny paper has promise?"

"Yes," I said. "The theological part at the end is a httle surprismg, coming from you, but I like it. I'in sure your professor will, too."

"I hope so. And keep your fingers crossed that the Federalist Society doesn't reject it out of hand when I send it in."

I had heard strains from the law school chorale group, which was practicing downstairs for its Christınas program.

"Title your last section 'Amazing Grace,' " I suggested.

Rodrigo looked back intently at me as he left iny office, his things under his arm. "I think I will," he said. 
